\title{
Antimicrobial resistance and detection of mecA and blaz genes in coagulase-negative Staphylococcus isolated from bovine mastitis ${ }^{1}$
}

\author{
Lidiane C. Soares ${ }^{2}$, Ingrid A. Pereira², Bruno R. Pribul' ${ }^{2}$, Marcelo S. Oliva², \\ Shana M.O. Coelho ${ }^{3}$ and Miliane M.S. Souza ${ }^{3 *}$
}

\begin{abstract}
Soares L.C., Pereira I.A., Pribul B.R., Oliva M.S., Coelho S.M.O. \& Souza M.M.S. 2012. Antimicrobial resistance and detection of mec and blaZ genes in coagulase-negative Staphylococcus isolated from bovine mastitis. Pesquisa Veterinária Brasileira 32(8):692-696. Departamento de Microbiologia Veterinária, Instituto de Veterinária, Universidade Federal Rural do Rio de Janeiro, BR 465 Km 7, Seropédica, RJ 23890-000, Brazil. E-mail: miliane@ufrrj.br

The present study evaluated the pheno- and genotypical antimicrobial resistance profile of coagulase-negative Staphylococcus (CNS) species isolated from dairy cows milk, specially concerning to oxacillin. Of $100 \mathrm{CNS}$ isolates, the $S$. xylosus was the prevalent species, followed by S. cohnii, S. hominis, S. capitis and S. haemolyticus. Only 6\% were phenotypically susceptible to the antimicrobial agents tested in disk diffusion assay. Penicillin and ampicillin resistance rates were significantly higher than others antimicrobials. Four isolates were positive to mecA gene (4\%), all represented by the $S$. xylosus species. The blaZ gene was detected in $16 \%$ of the isolates $(16 / 100)$. It was noticed that all mecA + were also positive to this gene and the presence of both genes was correlated to phenotypic beta-lactamic resistance. We conclude that CNS species from bovine milk presented significantly distinct antimicrobial resistance profiles, evaluated by phenotypic and genotypic tests, which has implications for treatment and management decisions.
\end{abstract}

INDEX TERMS: Mastitis, coagulase negative staphylococci, antimicrobial resistance, gene mecA, gene blaZ, cattle.

RESUMO.- [Resistência antimicrobiana e detecção dos genes mec e blaZ em Staphylococcus coagulase-negativos isolados de mastite bovina.] 0 presente estudo avaliou o perfil fenogenotípico de resistência aos antimicrobianos em espécies de Staphylococcus coagulase-negativo (ECN) isoladas do leite de vacas com mastite, em especial considerando a oxacilina. Dos 100 isolados de ECN, S.xylosus foi a espécie predominante, seguida por S. cohnii, S. hominis, S. capitis and S. haemolyticus Apenas 6\% dos isolados foram fenotipicamente suscetíveis aos agentes antimicrobianos testados no ensaio de difusão em disco. 0

\footnotetext{
${ }^{1}$ Received on December 30, 2011.

Accepted for publication on March 10, 2012.

${ }^{2}$ Curso de Pós-Graduação em Ciências Veterinárias, Instituto de Veterinária (IV), Universidade Federal Rural do Rio de Janeiro (UFRRJ), BR 465 Km 7, Seropédica, RJ 23890-000, Brazil.

${ }^{3}$ Laboratório de Bacteriologia Veterinária, Depto Microbiologia Veterinária, IV, UFRRJ, Seropédica, RJ. *Corresponding author: miliane@ufrrj.br
}

percentual de resistência à penicilina e ampicilina foi significativamente maior que aos outros antimicrobianos. Quatro isolados foram positivos para o gene mecA (4\%), sendo todos representados pela espécie S.xylosus. O gene blaZ foi detectado em $16 \%$ dos isolados $(16 / 100)$, sendo todos mecA positivos e a presença de ambos os genes foi correlacionada com a resistência fenotípica aos beta-lactâmicos. Foi possível concluir que as espécies de ECN provenientes de leite bovino apresentaram distintos perfis de resistência antimicrobiana, avaliados por testes fenotípicos e genotípicos, podendo dificultar a adoção de medidas de tratamento e manejo dos animais.

TERMOS DE INDEXAÇÃO: Mastite, estafilococos coagulase negativos, resistência antimicrobiana, gene mecA, gene blaZ, bovinos.

\section{INTRODUCTION}

Bovine mastitis is a multifactorial disease that results in reduced milk production, changes in milk composition and 
milk discard. It imposes serious economic losses for the farmers and the dairy industry (Ribeiro et al. 2003, Pitkala et al. 2004). Mastitis can be moderate or severe, and can be caused by many different bacterial species, mainly by Staphylococcus and Streptococcus strains (Pyorala, 2002). Nowadays coagulase-negative staphylococci (CNS) are of great interest in veterinary medicine because they are currently considered emerging pathogens of bovine mastitis. Although CNS are not as pathogenic as the other principal mastitis pathogens and infection mostly remains subclinical, they can cause persistent infections, which result in increased milk somatic cell count (SCC) and decreased milk quality (Pyorala 2002). Prevalent CNS species vary according to the geographical region under scrutiny (Huxley et al. 2002).

Antibiotic resistance is the most puzzling question of public healthy in the earlier decade of this $21^{\text {st }}$ century. Mastitis is the single most common reason for the use of antimicrobials in dairy cattle husbandry. Use of antimicrobial treatment is required for clinical mastitis, persistent infections and in heifers before calving (Taponen et al. 2006). Therefore, antimicrobial resistance of mastitis pathogens has received much interest over the past few years. Carriage of antimicrobial resistance genes by CNS species in cattle may also be relevant because it potentially poses a human health hazard. It can happens both through lateral transfer of resistance genes between staphylococcal species and through direct transmission of resistant pathogens (Walther \& Perreten 2007).

Among the antimicrobial agents approved for use in bovine mastitis, $\beta$-lactams, such as penicillins and cephalosporins, play a key role. Resistance to $\beta$-lactams in staphylococci is mediated by either $\beta$-lactamases codified by blaZ gene or mecA-encoded alternative penicillin binding protein, $\mathrm{PBP} 2 \mathrm{a}$, which shows a reduced binding to $\beta$-lacta$\mathrm{ms}$ antibiotics currently available for mastitis therapy. According to recommendations of the CLSI, oxacillin-resistant Staphylococcus isolates shall be reported as resistant to other $\beta$-lactam antibiotics (Aarestrup et al. 2006). Humans and dairy cattle may share CNS strains, implying that bovine staphylococcal multidrug resistant might be a zoonotic pathogen. It is difficult to demonstrate the direction of interspecies transmission, but it has been suggested that CNS is more likely to spread from humans to dairy cattle than vice versa (Thorberg et al. 2006).

This study was conducted to determine pheno- genotypic antimicrobial resistance profiles of CNS isolated from bovine milk to antibiotics of clinical relevance in dairy practice with emphasis on oxacillin in order to contribute to the knowledge of circulating CNS.

\section{MATERIALS AND METHODS}

\section{Sampling and Bacterial isolation and phenotypic identifica- tion}

Twenty five dairy cattle farms located in six different towns comprising an important milk production region of the State of Rio de Janeiro, Brazil, were selected due to its medium size, mechanical milking system and veterinary management. A total of 450 animals were evaluated by California Mastitis Test and 228 cows were positive for subclinical mastitis. Individual mammary quarter milk samples were aseptically collected into sterile vials immediately before milking, after discarding the first three milking streams. The milk samples were transported to laboratory and procedures of isolation and identification were performed following Koneman et al. (2008).

The isolates were initially identified by the Gram staining, catalase test and susceptibility to $0.04 \mathrm{U}$ bacitracin (CECON, São Paulo, Brazil) to characterize the genus Staphylococcus (Bannerman 2003). Twelve tests were used as following: coagulase, nitrate reduction, urease production and acid production from D-trehalose, sucrose, xilose, a-lactose, D-mannitol, fructose, maltose and D-mannose. CNS isolates from our collection that were previously characterized were used as controls in assays.

\section{Phenotypic antimicrobial tests}

The inoculum was obtained from overnight broth cultures and adjusted to achieve approximately $5 \times 10^{5} \mathrm{CFU} / \mathrm{ml}$ considering a turbidity equivalent to a 0.5 McFarland standard (CLSI, 2010). Disk diffusion test was employed to determine the susceptibility of penicillin (10UI), ampicillin $(10 \mu \mathrm{g})$, oxacillin $(1 \mu \mathrm{g})$, ampicillinsulbactam $(10 / 10 \mu \mathrm{g})$, cefalotine $(30 \mu \mathrm{g})$, vancomicin $(30 \mu \mathrm{g})$, gentamicin $(10 \mu \mathrm{g})$, tetraciclin $(30 \mu \mathrm{g})$, enrofloxacin $(10 \mu \mathrm{g})$, and trimethoprim-sulfamethoxazole $(1,25 / 23,75 \mu \mathrm{g})$, (SENSIFAR-CEFAR ${ }^{\circledR}$ ) agents. Strains resistant to above two antimicrobial classes were considered multiresistant. Multiresistant Staphylococcus aureus ATCC43300 was used as positive control (CLSI, 2008). Controle do teste de antibiograma. Que ATCC foram utilizadas?

Oxacillin susceptibility tests comprised disk diffusion with oxacillin (SENSIFAR-CEFAR ${ }^{\circledR}$ - 1mg) and cefoxitin discs (SENSIFARCEFAR $^{\circledR}$ - 30mg). Also Minimal Inhibitory Concentrations (MICs) of oxacillin were determined by agar and broth dilution methods where oxacillin concentrations ranging from 0,25 to $256 \mu \mathrm{g} / \mathrm{mL}$ were added to Mueller-Hinton (Difco, Detroit, MI, USA) supplemented with $2 \%$ of $\mathrm{NaCl}$ and MICs were recorded after $24 \mathrm{~h}$ of incubation at $35^{\circ} \mathrm{C}$. Importante informar em que temperatura $\mathrm{o}$ teste foi realizado. The MIC used to predict mecA presence was 8 $\mu \mathrm{g} / \mathrm{ml}$ (Kohner et al, 1999). Resistance to oxacillin was also evaluated by agar screening using Mueller-Hinton agar supplemented with $4 \%$ of $\mathrm{NaCl}$ and $6 \mu \mathrm{g} / \mathrm{mL}$ of oxacillin. The plates were examined carefully for evidence for small colonies ( $<1$ colony) indicating oxacillin resistance. All the results were interpreted according to CLSI (2010) recommendations.

For beta-lactamase production it was used a nitrocefin disk test (Oxoid $囚$ ) according to the manufacturer's instructions.

\section{PCR amplification}

DNA was extracted by the lisostaphin method as previously described (Coelho et al. 2009). Polymerase chain reaction for detection of genes mecA(513 bp) and blaZ ( $639 \mathrm{bp})$ were carried out using the following primers: 5' AAA ATC GAT GGT AAA GGT TGG C 3' AGT TCT GCA GTA CCG GAT TTG C and 5' TAC AAC TGT AAT ATC GGA GGG 3' CAT TAC ACT CTT GGC GGT TTC, respectively. Amplification cycles for mecA were done according to Coelho et al. (2009) considering 40 cycles of $94^{\circ} \mathrm{C} 30 \mathrm{~s}, 55^{\circ} \mathrm{C} 30 \mathrm{~s}, 72^{\circ} \mathrm{C} 1 \mathrm{~min}$ with a final extension of $72^{\circ} \mathrm{C} 5 \mathrm{~min}$. The blaZ amplification was performed according Rosato et al (2003) considering a initial denaturation of $94^{\circ} \mathrm{C} 5 \mathrm{~min}$ followed by 35 cycles of $94^{\circ} \mathrm{C} 30 \mathrm{~s}, 55^{\circ} \mathrm{C}$ $30 \mathrm{~s}, 72^{\circ} \mathrm{C} 30 \mathrm{~s}$. with a final extension of $72^{\circ} \mathrm{C} 5 \mathrm{~min}$. Staphylococcus aureus ATCC43300 mecA + and blaZ + was used as strain control (CLSI, 2008).

The amplicons were evaluated by agarose gel electrophoresis followed by staining in ethidium bromide $(0.5 \mathrm{mg} / \mathrm{mL})$, visualized on UV transilluminator and documented by the program 
QuantiOne (BioRad) using molecular weight markers of $100 \mathrm{bp}$ (Fermentas ®).

The association between phenotypic or genotypic resistance was explored using Chi-square or Fisher exact statistics, as appropriate in Statistix 8.0 (Analytical Software, Tallahassee, FL).

\section{RESULTS}

Identification of coagulase-negative Staphylococcus spp.

A total of 100 CNS isolates was obtained from the milk samples evaluated, included $70 \%$ of S.xylosus, $10 \%$ S. cohnii, 8\% S. hominis, 7\% S. capitis and 5\% Staphylococcus haemolyicus.

\section{Antibiotic susceptibility test}

Results of the in vitro disk diffusion assays of CNS susceptibility are summarized in Table 1. A highest resistance was observed against penicillin, ampicillin and tetracyclin. Associations of ampicillin+sulbactam and trimethropin+sulfametoxazole were the most effective antibiotics. It was also detected multiresistant isolates considering resistance above two antimicrobial classes (Table 2). Nine different resistance patterns were identified among the 100 strains. The most frequently observed pattern of multiple resistance was the penicillin-ampicillin-oxacillin-tetraciclin combination, found in 23 (23\%) strains.

\section{Oxacillin susceptibility phenotypic testing}

All 100 CNS was analysed for oxacillin susceptibility by disc diffusion, broth and agar microdilution, agar screening and cefoxitin disc test following CLSI standards (2010). These susceptibility tests revealed 15 distinct profiles sho-

Table 1. Percentage of antimicrobial resistance of coagulase-negative Staphylococcus

\begin{tabular}{lc}
\hline Antibiotics & $\begin{array}{c}\text { Percentage (\%) of } \\
\text { antimicrobial resistance }\end{array}$ \\
\hline Penicillin & 79 \\
Ampicillin & 79 \\
Tetracyclin & 64 \\
Oxacillin & 29 \\
Gentamicin & 15 \\
Cefalotine & 7 \\
Enrofloxacin & 2 \\
Ampicillin-sulbactam & 0 \\
Vancomicin & 0 \\
Trimethoprim-sulfamethoxazole & 0
\end{tabular}

Table 2. Antimicrobial resistance profile of isolates of coagulase-negative Staphylococcus

\begin{tabular}{cccc}
\hline Profile & Resistance phenotypes & $\begin{array}{c}\text { Number of } \\
\text { strains }\end{array}$ & $\begin{array}{c}\text { Number of antibiotic } \\
\text { classes }\end{array}$ \\
\hline 1 & PEN, AMP, OXA, TET & 24 & 2 \\
2 & PEN, AMP & 23 & 1 \\
3 & TET & 15 & 1 \\
4 & PEN, AMP, TET & 10 & 2 \\
5 & PEN, AMP, TET, GEN & 8 & 3 \\
6 & PEN, AMP, TET, GEN, CFL & 7 & 4 \\
7 & -* & 6 & - \\
8 & PEN, AMP, OXA & 5 & 1 \\
9 & PEN, AMP, ENO & 2 & 2
\end{tabular}

*(-) sensible to all tested antimicrobials. wn in Table 3. Broth microdilution yielded the highest level of resistant strains (40\%).

\section{mec and bla genes detection}

The mecA gene was detected in 13.8\% (4/29) of oxacillin resistant CNS, represented strictly by Staphylococcus xylosus. The blaZ gene was detected in 55\% (16/29) of the CNS isolates, all of them presented resistance in nitrocefin test.

Table 3. Oxacillin resistance profiles of coagulase-negative Staphylococcus spp. in distinct phenotypic tests

\begin{tabular}{cc}
\hline Profile (number of resistant isolates) & Tests* \\
\hline $1(40)$ & MC \\
$2(11)$ & - \\
$3(9)$ & DM,AS \\
$4(8)$ & DD,AS,MP,MC \\
$5(7)$ & DM,MC \\
$6(6)$ & DD,DM,AS,MP,MC \\
$7(5)$ & DD,AS,MC \\
$8(4)$ & DD,DM,MP,MC \\
$9(2)$ & DM,MP,MC \\
$10(2)$ & DD,DM,AS,MC \\
$11(2)$ & DD \\
$12(1)$ & DM,AS,MP,MC \\
$13(1)$ & DM \\
$14(1)$ & DD,MC \\
$15(1)$ & DD,DM,MC \\
*DD = disk diffusion, MD = modified disk diffusion, AS = agar screen, MP = \\
agar microdilution, MC = broth microdilution.
\end{tabular}

\section{DISCUSSION}

We detected Staphylococcus xylosus as the predominant specie. Despite variations between herds and countries, others CNS i.e. S. chromogenes, S. simulans and S. epidermidis, in general, appear to be the most frequently isolated CNS from mammary secretion samples worldwide (De Vliegher et al. 2003, Taponen et al. 2006). Identification to species level would be important if it reflects differences in virulence characteristics or epidemiology, e.g. in somatic cell count elevation (Sampimon et al. 2009), persistence (Taponen et al. 2006) or transmissibility, and if it has impact on management and treatment decisions. Correct species identification is important for mastitis control and in epidemiological investigations, as well as in understanding of the significance of infections caused by different CNS species.

Antimicrobial resistance profiles differed significantly between CNS species from milk of dairy cattle (Sampimon et al. 2009). In the present work, the highest resistance rate was observed against penicillin, ampicillin and tetracyclin. Penicillin and ampicillin resistance in Staphylococcus spp. is a worldwide phenomenon, with increasing prevalence, despite the selective pressure enforced by the improper use of beta-lactams in mastitis treatment (Bonna et al. 2007). The emergence of high levels of penicillin resistance followed by the development and spread of strains resistant to the semisynthetic penicillins (methicillin, oxacillin, and nafcillin), macrolides, tetracyclines, and aminoglycosides has made the therapy of staphylococcal disease a global challenge. The tetracycline resistance detected can be at- 
tributed to the large use of this antibiotic in mastitis treatment and in the water of the herd as a prophylactic measure aimed at reducing infections (Booth \& McDonald 1992).

It was detected that the association of an antibiotic and a beta-lactamase inhibitor, ampicillin+sulbactam and a nucleic acid synthesis inhibitor, trimethropin+sulfametoxazole were the most effective antibiotics. In human clinical cases, the use of beta-lactamase inhibitor is an alternative in case of beta-lactam resistant bacteria (Gentilini et al. 2002). In animal production system it does not worthy because of its high cost. Otherwise, the efficiency of a beta-lactamase inhibitor associated with the detection of blaZ gene in 55\% of oxacillin-resistant strains and positive results obtained from nitrocefin test gives us a clue that beta-lactamases must be greatly implicated in the detected resistance. The widespread use of antibiotics has been responsible for the emergence of multidrug resistant bacteria. Antibiotic use in subtherapeutic levels as growth promoters is still common in Brazilian animal production including dairy farms. In the present study, it was observed multiresistance from two to four tested antimicrobial classes. In their report, Machado et al. (2008) detected that all CNS isolates from bovine mastitis showed resistance to two or more antimicrobial agents.

During recent years, methicillin resistance in animals has gained particular attention from public health authorities. It is known that the use of antimicrobials for mastitis treatment can promote emergence or survival of MRSA (Staphylococcus aureus methicillin resistant) and others methicillin resistant staphylococci in dairy cattle (Moon et al. 2007, Garcia-Alvarez et al. 2009). It has also been hypothesized that MRCNS (methicillin resistant coagulase negative Staphylococcus) of agricultural animals may serve as important reservoirs for the transfer of antimicrobial resistance genes. Nevertheless, little information is available on methicillin-resistant CNS (MRCNS) from dairy cattle (Febler et al. 2010).

As methicillin resistance and multidrug resistance in bovine CNS have been described before (Sawant et al. 2009, Fessler et al. 2010) further evaluations of oxacillin resistance were performed by different methods. Since oxacillin maintains its activity during storage better than methicillin, laboratory diagnosis of methicillin resistance is based on the testing of oxacillin. Accurate detection of oxacillin/methicillin resistance can be difficult due to the possible coexistence of two subpopulations (susceptible and resistant) within a culture termed heteroresistance. It is a problem for clinical laboratory personnel because cells expressing resistance may grow slowly than the susceptible population. This heterogeneity can lead to failure of treatment due to false appearance of susceptibility In this study, the highest resistance rate from oxacillin susceptibility assays was detected in the broth microdilution. Despite its sensivity, it is a very laborious and subjective assay, so veterinary CLSI (2008) recommends agar screen and disk diffusion as standard tests for oxacillin evaluation in animal samples.

Althoug a low level of mecA gene was detected, methicillin resistance can be attributed to other mechanisms like inactivation of oxacillin by increased production of beta-lactamase, codified by blaZ gene. In the present work, a significant blaZ gene prevalence was observed in oxacillin resistant strains. Also all blaZ isolates were mecA+.

\section{CONCLUSIONS}

This study showed high incidence of CNS from bovine mastitic milk, specially Staphylococcus xylosus, what is not so commonly reported in literature.

Beta-lactam resistance was found to be widely spread among isolates.

Fifty one isolates were found to be multiresistant and this finding is rather relevant because of the importance of this antimicrobial class in dairy industry.

The susceptibility of oxacillin-resistant strains to beta-lactames inhibitor association pointed to the implication of beta-lactamase production in the detected resistance.

$B l a \mathrm{Z}+m e c \mathrm{~A}+$ strains were resistant to all evaluated beta-lactamics.

Acknowledgements.- This study was funded by CNPq and FAPERJ (E26/171.360/2005, Proc. E-26/171.366/2006, E-26 /110.910/2008).

\section{REFERENCES}

Aarestrup F.M. \& Schwarz S. 2006. Staphylococci and streptococci, p.187206. In: Aarestrup F.M. (Ed.), Antimicrobial Resistance in Bacteria of Animal Origin. ASM Press, Washington, DC.

Bannerman T.M. 2003. Staphylococcus, Micrococcus and other catalase-positive cocci that grow aerobically, p.384-404. In: Murray P.R. (Ed.), Manual of Clinical Microbiology. Vol.1. $8^{\text {th }}$ ed. ASM Press, Washington, DC.

Bonna I.C.F., Santos A.P.V., Teixeira G.N. \& Motta O.V. 2007. Staphylococcus coagulase-negativos resistentes a drogas isolados de leite de búfalas (Bubalus bubalis) [Drug resistant coagulase-negative Staphylococci isolated from milk of buffaloes (Bubalus Bubalis). Revta Bras. Ciênc. Vet. 14:117-121.

Booth N. \& McDonald L.E. 1992. Farmacologia e Terapêutica em Veterinária. $6^{\text {th }}$ ed. Guanabara Koogan, Rio de Janeiro. 997p.

Clinical and Laboratory Standards Institute 2008. Performance Standards for Antimicrobial Disk and Dilution Susceptibility Tests for Bacteria Isolated from Animals. $3^{\text {rd }}$ ed. M31-A3. CLSI, Wayne, PA.

Clinical and Laboratory Standards Institute 2010. Performance Standards for Antimicrobial Susceptibility Testing. $20^{\text {th }}$ Informational Supplement, M100-S20. CLSI, Wayne, PA.

Coelho S.M.O., Reinoso E., Pereira I.A., Soares L.C., Demo M., Bogni C. \& Souza M.M.S. 2009. Virulence factors and antimicrobial resistance of Staphylococcus aureus isolated from bovine mastitis in Rio de Janeiro. Pesq. Vet. Bras. 29:369-374.

De Vliegher S., Laevens H., Devriese L.A., Opsomer G., Leroy J.L., Barkema H.W. \& De Kruif A. 2003. Prepartum teat apex colonization with Staphylococcus chromogenes in dairy heifers is associated with low somatic cell count in early lactation. Vet. Microbiol. 92:245-252.

Febler A.T., Billerbeck C., Kadlec K. \& Schwarz S. 2010. Identification and characterization of methicillin-resistant coagulase-negative staphylococci from bovine mastitis. J. Antimicrob. Chemother. 65:1576-1582.

Fessler A.T., Billerbeck C., Kadlec K. \& Schwarz S. 2010. Identification and characterization of methicillin-resistant coagulase-negative staphylococci from bovine mastitis. J. Antimicrob. Chemother. 65:1576-1583.

Garcia-Alvarez L., Lindsay H., Brown D.F., Curran M.D., Walpole E., Holden M.T., Maskell D.J., Bentley S.D., Webb C.R. \& Holmes M.A. 2009. Discovery and characterization of a novel bovine associated methicillin-resistant Staphylococcus aureus isolate. ASM Conferences Methicillin-Resistant Staphylococci in Animals: Veterinary and Public Health Implications, Sept. 22-25, London, p.35. 
Gentilini E., Denamiel G., Betancor A., Rebuelto M., Fermepin M.R. \& De Torres R.A.J. 2002. Antimicrobial susceptibility of coagulase-negative staphylococci isolated from bovine mastitis in Argentina. Am. Dairy Sci. 85:1913-1917.

Huxley J.N., Greent M.J., Green L.E. \& Bradley A.J. 2002. Evaluation of the efficacy of an internal teat sealer during the dry period. J. Dairy Sci. 85:551-561.

Kohner J.P., Uhl J., Kolbert C., Persing D. \& Cockerill F.A. 1999. Comparison of susceptibility testing methods with $m e c A$ gene analysis for determining oxacilin (methicilin) resistance in clinical isolates of Staphylococcus aureus and coagulase-ative Staphylococcus spp. J. Clin. Microbiol. 37:2952-2961.

Koneman E.W., Allen S.D. \& Janda W.M. 2008. Diagnóstico Microbiológico. $5 \stackrel{a}{a}$ ed. Editora MEDSI, Rio de Janeiro. 1465p.

Machado T.R.O., Correa M.G. \& Marin J.M. 2008. Antimicrobial susceptibility of coagulase-negative staphylococci isolated from mastitic cattle in Brazil. Arq. Bras. Med. Vet. Zootec. 60:278-282.

Moon J.S., Lee A.R. \& Kang H.M. 2007. Phenotypic and genetic antibiogram of methicillin-resistant staphylococci isolated from bovine mastitis in Korea. J. Dairy Sci. 90:1176-1185.

Pitkala A., Haveri M., Pyorala S., Myllys V. \& Honkanen-Buzalski T. 2004. Bovine mastitis in Finland 2001: Prevalence, distribution of bacteria, and antimicrobial resistance. J. Dairy Sci. 87:2433-2441.

Pyorala S. 2002. Trends and advances in mastitis therapy, p.360-368. In: Kaske M., Scholz H. \& Höltershinken M. (Eds), Recent Developments and Perspectives in Bovine Medicine. Keynote Lectures in XXII World Buiatrics Congress, Hannover. Hildesheimer Druck and Verlag GmbH, Hildesheim, Germany.
Ribeiro M.E.R., Petrini L.A., Aita M.F., Balbinotti M., Stumpf Jr W., Gomes J.F., Schramm R.C., Martins P.R. \& Barbosa R.S. 2003. Relation between clinical, subclinical infectious and noninfectious mastitis in milk production units in the southern region of the Rio Grande do Sul State. Revta Bras. Agrociência 9:287-290.

Rosato A.E., Kreiswirth B.N., Craig W.A., Eisner W., Climo M. \& Archer G.L. 2003. mecA-blaZ corepressors in clinical Staphylococcus aureus isolates. Antimicrob. Agents Chemother. 47:1460-1463.

Sampimon O.C., Zadoks R.N., De Vliegher S., Supre K., Haesebrouck F., Barkema H.W., Sol J. \& Lam T.J.G.M. 2009. Performance of API StaphID 32 and Staph-Zym for identification of coagulase-negative staphylococci isolated from bovine milk samples. Vet. Microbiol. 136:300-305.

Sawant A.A., Gillespie B.E. \& Oliver S.P. 2009. Antimicrobial susceptibility of coagulase-negative Staphylococcus species isolated from bovine milk. Vet. Microbiol. 134:73-81.

Taponen S., Simojoki H., Haveri M., Larsen H.D. \& Pyorala S. 2006. Clinical characteristics and persistence of bovine mastitis caused by different species of coagulase-negative staphylococci identified with API or AFLP. Vet. Microbiol. 115:199-207.

Thorberg B.M., Ku H.N.I., Aarestrup F.M., Brandstrom B., Jonsson P. \& Danielsson-Tham M.L. 2006. Pheno- and genotyping of Staphylococcus epidermidis isolated from bovine milk and human skin. Vet. Microbiol. 115:163-172.

Walther C. \& Perreten V. 2007. Letter to the editor: Methicillin-resistant Staphylococcus epidermidis in organic milk production. J. Dairy Sci. 90:5351. 